\title{
Apuntes de poética narrativa. Florecimiento y ocaso de la novela histórica mexicana en el siglo XIX
}

\section{Notes of poetic narrative. Rise and decline of the Mexican historical novel in the nineteenth century}

\author{
Gerardo Francisco Bobadilla Encinas \\ Universidad de Sonora, México
}

Resumen: La novela histórica fue el género literario dominante de la literatura mexicana entre 1836-1870, condicionada tanto por la circunstancia histórica del país como por la concepción de lo literario durante la época. Luego de la pacificación y consolidación de México a partir del orden y progreso positivista que desarrolló la República Restaurada (1867-1876) y el porfiriato (1876-1911), la concepción y función de la historia y de la novela histórica en México se replantearon y dio inicio un proceso de declinación que condujo a su ocaso.

El objetivo del presente trabajo está encaminado a describir e interrelacionar algunos de los distintos aspectos que marcaron el florecimiento y ocaso de la novela histórica dentro de la tradición literaria mexicana del siglo XIX, desde una perspectiva de estudio semiótica, integral, que busca apuntar dinámicamente al menos los elementos más destacados que participaron en el proceso.

Palabras clave: relaciones historia-literatura, novela histórica mexicana, historia de la novela en México, literatura como Bellas letras, literatura como Bella arte. 
Summary: The historical novel was the dominant literary genre of Mexican literature between 1836 and 1870, conditioned by the historical circumstance as much as by the conception of the literary during the time. After the pacification and consolidation of Mexico from the positivist order and progress developed by the Restored republic (1967-1976) and the porfiriato (1876-1911), the conception and function of the history and the historical novel in Mexico were rethought and began its process of decline.

The aim of this work is precisely to describe and interrelate some of the different aspects that marked the flourishing and decline of the historical novel in the nineteenth century Mexican literary tradition, from a semiotic and integral perspective that seeks to explain dynamically at least the most outstanding elements who participated in the process.

Keywords: History-literature relations, Mexican historical novel, History of the novel in Mexico, Literature as Fine letters (Bellas letras), Literature as Fine art (Bella arte).

Recibido: 7 de septiembre de 2017 Aceptado: 2 de marzo de 2018

Tgnacio Manuel Altamirano afirmaba en su artículo "La literatura mexicana en 1870. La novela” que "aquí [en México] no se ha cultivado sino la novela histórica, y muy poco la de sentimiento, la verdadera novela. Para la instrucción popular, es evidentemente más útil la primera[;] para la belleza literaria se presta más la segunda" (1988: 235). Si bien habría que explicar los matices de la diferenciación entre la utilidad ética y la armonía estética del texto literario desde los parámetros interpretativos y valorativos de su tiempo, lo importante es que el escritor guerrerense reconoce y establece el papel dominante que tuvo el subgénero en la articulación de la tradición cultural y literaria mexicana durante las cinco primeras décadas de vida independiente, al contribuir a conformar un imaginario histórico y cultural patriótico que coadyuvara en la unidad nacional y que contrarrestara así la inestabilidad política, 
moral, histórica e ideológica que siguió a la consumación de la independencia del país en 1821.

La historia de la literatura mexicana más tradicional ha hecho suya esta afirmación y parte de ella para explicar el origen y primer desarrollo del género novelesco en México entre los años de 1836 y 1870 aproximadamente, como señalan en sus textos John Lloyd Read, Julio Jiménez Rueda y Emmanuel Carballo, entre otros estudiosos. ${ }^{1}$ Sin embargo, al tomar esta consideración como punto de partida, por repetido, acríticamente asumido, no se han advertido ni problematizado mayormente las distintas resoluciones éticas y estéticas que asumió la novela histórica durante la centuria decimonona como proceso cultural e histórico específico ni se ha tomado en cuenta tampoco el papel que en ello desempeñaron las diferentes concepciones y funciones de lo literario, así como el condicionamiento sucesivo y vertiginoso de los diversos imaginarios articulados durante la época como parte del desarrollo de la identidad nacional y de la consolidación de la independencia recién lograda. En este contexto, pues, el reconocimiento y estudio integrado de dichos elementos y/o procesos, a la vez que permiten describir y explicar la integralidad semiótica de la presencia dominante del subgénero en el periodo, permiten comprender también su posterior cultivo y existencia marginal durante el último cuarto del siglo XIX, particularidades que abordaré a continuación.

No puede entenderse la apropiación y desarrollo de la novela histórica decimonona como subgénero dominante dentro del periodo fundante de la tradición cultural y literaria de México

${ }^{1}$ Véase Carlos González Peña, Historia de la literatura mexicana. Desde sus orígenes hasta nuestros dias (1926); John Lloyd Read, The Mexican Historical Novel (1939); Julio Jiménez Rueda, Letras mexicanas en el siglo XIX (1944); Ralph Warner, Historia de la novela mexicana (1953); Emmanuel Carballo, Historia de las letras mexicanas en el siglo XIX (1991); Eva Lidia Oseguera de Chávez, Historia de la literatura mexicana en el siglo XIX (1991). 
(1836-1870), sin entender ni explicar la caracterización y función de las distintas manifestaciones genéricas agrupadas entonces bajo el rubro de 'poesía' como realizaciones de las Bellas letras. Así, al partir de que para finales del siglo XVIII en el contexto cultural de occidente se habían superado las farragosas diatribas del academicismo neoclásico que criticaban y buscaban superar mediante la negación los excesos de la estética barroca, puede advertirse que poco a poco, entre los intelectuales y escritores de occidente, fue articulándose una concepción de la literatura y/o de lo literario no sólo como el seguimiento y respeto fiel a las preceptivas clásicas (como reduccionista y mecánicamente se ha entendido y estudiado hasta ahora) sino también se empezó a comprender como un campo cultural que integraba por medio de la escritura las distintas expresiones de la vida y la cultura; planteamientos que, a partir de la influencia de la cultura francesa, se realizaron en el contexto hispánico por eruditos como Francisco Javier Lampillas en Ensayo histórico-apologético de la literatura española contra las opiniones preocupadas de algunos escritores modernos italianos (17821789), José Luis Munárriz en Lecciones sobre la Retórica y las Bellas Letras (1798-1799) o Agustín García de Arrieta en Principios filosóficos de la literatura o Curso razonado de Bellas letras y de Bellas artes (1805). Estas mismas concepciones subyacen y determinan el planteamiento y ejecución de la inacabada Bibliotheca mexicana (1755), de Juan José Eguiara y Eguren, de la Gaceta de literatura de México (1787-1795), de José Antonio Alzate y Ramírez, o de la Biblioteca Hispano-Americana Septentrional (1816-1821), de José Mariano Beristain de Souza, por mencionar sólo unos cuantos ejemplos. En este contexto, tal como señala Agustín García de Arrieta en la refundición del Curso razonado de Bellas letras y de Bellas artes, la literatura se entiende como "el conocimiento de las Bellas letras", esto es "el conocimiento de los grandes modelos en poesía, elocuencia, historia, filosofía moral y política, ora sea de los 
antiguos, ora de los modernos" (García de Arrieta, 1797: 338). Y añade, puntualizando, que

la literatura no sólo es [o refiere] el conocimiento de la Poesía y de la Elocuencia; es propiamente el estudio y conocimiento de todas las bellas letras, de las letras humanas, humaniorumlitterarum, como las llamaban los Antiguos. Ofrece [...] la historia razonada de todas las artes del espiritu y de la imaginación: en fin, comprehende [...] todo quanto los Antiguos atribuían al Gramático, al Poeta, Orador y Filósofo; y sólo excluye las ciencias físicas, y las ciencias exactas (García apud. Gunia, 2008: 211; el énfasis es mío).

La concepción de la literatura como Bellas letras o como Letras humanas que engloba prácticamente la totalidad del conocimiento humanístico expresado y sistematizado a través de la palabra escrita -esto es de la historia, la filosofía, el derecho, la poesía, la gramática, la elocuencia- fue particularmente importante, pues integraba las distintas ramas y manifestaciones de la cultura escrita a partir de reconocerles una "finalidad persuasiva y didáctica" (Aradra, 1997: 171), gracias a la cual participan directa y activamente tanto en la articulación como en la comprensión, validación y difusión de los códigos valorativos e interpretativos, así como de los imaginarios que dan significado a un entorno socio-histórico y cultural específico en un momento determinado, independientemente de las estructuras y recursos particulares que despliegan los distintos discursos concretos para su realización textual. Tal como lo señalan Rosa María Aradra Sánchez en De la retórica a la teoría de la literatura: siglos XVIII y XIX (1997), Inke Gunia en De la poesia a la literatura. El cambio de los conceptos en la formación del campo literario español del siglo XVIII y principios del XIX (2008), Bernarda Urrejola en "El concepto de literatura en un momento de su historia: el caso mexicano (1750-1850)" (2011), al menos durante la segunda parte del siglo XVIII y las primeras tres cuartas 
partes del siglo XIX, esto es hasta 1876 aproximadamente, el concepto y el ejercicio de la literatura en general -los de la poesía en lo propio- no se oponen al concepto y ejercicio ni de la historia ni a los de derecho ni a los de filosofía ni a los de gramática ni a los de elocuencia, sino que se conciben como discursos escriturarios homólogos, copartícipes de un mismo campo y función cultural: el de las Bellas letras, "pues no parece haberse instalado aún la larga discusión entre realidad y ficción, entre subjetividad y objetividad, entre observación de la realidad y construcción de la realidad" (Urrejola, 2011: 1705) al que conduciría la modernidad positivista de finales del siglo XIX.

Es en este contexto histórico y cultural, pues, que adquiere particular relevancia la consideración de Ignacio Manuel Altamirano sobre la novela histórica como el género dominante de la primera etapa del desarrollo del género novelístico en México, comprendido entre 1821 y 1870 aproximadamente. Si bien hay aspectos e interrelaciones que habría que profundizar y/o matizar -como la noción de verdad y verosimilitud manejadas en la época, los factores y tipos del proceso de lectura y recepción, etcétera-, considero que el subgénero definido por Walter Scott en Escocia allá en 1814 con la publicación de Waverly, en los inicios de la época moderna, se estableció en nuestra tradición cultural y literaria como la resolución artística a partir de la cual la poesía, como expresión específica de un campo cultural más amplio, el de las Bellas letras, colaboraría junto con las otras manifestaciones literarias (historia, derecho, retórica, etcétera) en la construcción de un imaginario histórico que, al definir perfiles particulares para el hombre y la cultura, ayudaría a sustentar la unidad nacional que justificara y diera sentido, proyección al porvenir, a la independencia alcanzada en 1821, permitiendo así el desarrollo de un proyecto de nación común. 
Como señalé antes, al apoyarme en Altamirano, la presencia dominante de la novela histórica en la tradición literaria nacional abarcó entre 1836-1870 aproximadamente. Por eso, éste fue uno de los periodos históricos y culturales más convulso y contradictorio, más dinámico, que vivió el país durante la centuria. Durante ese lapso, se implementaron sucesivamente distintos modelos políticos (República central vs. República federal, República vs. monarquía), ideológicos (federalismo vs. centralismo, conservadurismo vs. liberalismo), económicos (liberalización vs. proteccionismo) y, particularmente importante para el reconocimiento y estudio de las poéticas y/o resoluciones artísticas de la historia, se definieron y articularon distintos discursos e imaginarios en torno a la caracterización y comprensión del hombre, la historia y la cultura en México. Así, al Nacionalismo criollo que estuvo vigente entre 1821 y 1860 aproximadamente -el cual estableció la figura y los valores del criollo como la entidad humana, cultural e histórica capaz de superar las inercias y vicios de la Colonia (1521-1821) y de darle un sentido y representatividad al México independiente-, le sustituyó el liberalismo reformista y positivista entre 1870 y 1911, que alrededor de la figura del mestizo articuló un entramado o modelo socio-histórico y cultural moderno y progresista (primero, de los parámetros liberales estadounidenses durante la República Restaurada; después, asumiendo los estándares ingleses y franceses de la época, los paradigmas de la modernidad decimonona durante el porfiriato).

Fue en este contexto, pues, que la Novela histórica comenzó a cultivarse y a tener una presencia genérica dominante, primero de manera aislada y esporádica, con temática diversa ,en obras como Xicoténcatl (1826), de autor anónimo, o El misterioso (1836), de Mariano Meléndez y Muñoz, pero de forma constante y destacada a partir de 1836 con la fundación de la Academia de Letrán y con 
su proyecto de mexicanizar temáticamente la literatura ${ }^{2}$ así como la publicación de sus distintos órganos de difusión: periódicos y revistas literarios y culturales. Para ello, al partir de una definición bastante amplia del subgénero, como aquella formalización literaria que habla del pasado para reconocer y explicar desde él ciertas características históricas y culturales del presente con base en el establecimiento de una distancia temporal que permite al narrador una descripción y explicación objetivas (Díaz 1991: 8283), la novela histórica en México definió y desarrolló sendas y distintas poéticas narrativas de la historia que marcaron toda una época, al menos hasta principios de la siguiente centuria: la novela histórica antiespañolista, la novela histórica de la independencia y la novela histórica de la consolidación liberal Esta periodización responde a una concepción semiótica del texto artístico, es decir, como entramado ético y estético de elementos y factores temáticos e ideológicos que determinan y, dialécticamente, están determi-

${ }^{2}$ Considero que el proyecto cultural y literario de mexicanización de la literatura articulado por la Academia de Letrán se ubicó, preferentemente, en el nivel temático, pues los poetas, narradores, ensayistas y dramaturgos pertenecientes a la asociación, en su afán por coadyuvar en la construcción de una identidad, de una imagen de México y el mexicano, abordaron los tópicos históricos, culturales y costumbristas desde una perspectiva intelectual -o ideológica si se prefiere-, no en su integralidad semiótica, ética y estética, que los hubiera hecho abordar y problematizar las formas y mecanismos lingüísticos y literarios de esa representación. Por ello, pese a los constantes señalamientos críticos de personajes como Manuel Carpio, José Joaquín Pesado o el Conde de la Cortina, referidos a "problemas" prosódicos, a giros lingüísticos del español mexicano que afectaban métricas y ritmos (cosa que en 1857 señala incluso José Zorrilla en México y los mexicanos), considero que el proyecto de mexicanización de la literatura desarrollado por los lateranenses centró sus esfuerzos en el ámbito de las ideas, más que en una problematización discursiva.

En este contexto, cabe apuntar que le corresponderá al Liceo Hidalgo y a la lucidez y guía de Ignacio Manuel Altamirano durante el último tercio de la centuria, el planteamiento y práctica de un proyecto literario nacional que incorporó y correlacionó temas, formas y lenguajes. 
nados por específicas resoluciones formales, estructurales (Bajtin, 1989; Lotman 1977, 1979).

Como se ha planteado en "Antiespañolismo y novela en México entre la primera y la segunda independencia. Replanteamientos góticos y mitificaciones fundacionales" (2011), hay que reconocer y ubicar el surgimiento de la novela histórica en relación con el sentimiento antiespañolista que marcó al menos las cuatro primeras décadas de vida independiente, entre 1825 y 1870 aproximadamente, periodo durante el cual los narradores mexicanos escribieron inicialmente novelas cortas antihispanistas o "novelitas" como las llamaban los mismos autores para ser publicadas en los periódicos y revistas culturales de la época; ${ }^{3}$ para después dedicarse a las novelas de folletín, con cuyas formulaciones novelescas los narradores mexicanos plantearon la aspiración a la independencia, a la emancipación mental y cultural a partir de concientizar y negar los valores, actitudes y conductas que determinó e impuso España en México durante los trescientos años de coloniaje (1521-1821), ${ }^{4}$ asumiendo un orgullo y modelo del mundo criollo a partir del cual, supuestamente, se superaría la dependencia con la antigua metrópoli. Estas novelas se caracterizaron por configurar el espacio-tiempo colonial desde una perspectiva gótica, esto es, como un lugar físico, moral e ideológicamente oscuro, supersticioso y opresor, en el cual se desenvolvían dos grupos de personajes dual y maniqueamente configurados: por un lado, el español domina-

${ }^{3}$ De estas se pueden consignar: "El inquisidor de México", de José Joaquín Pesado; "El visitador" y "La hija del Oídor", de Ignacio Rodríguez Galván; "El criollo", de José Ramón Pacheco, y "Netzula", de José María Lafragua, entre otras. ${ }^{4}$ Tal como lo planteó Justo Sierra O'Reilly en La hija del judio (1847-1849) y lo retomaron y desarrollaron posteriormente Eligio Ancona en La cruz y la espada (1864), Pascual Almazán en Un hereje y un musulmán (1870), Cresencio Carrillo Ancona en Historia de Welina (1883) y, de manera magistralmente resuelta, Vicente Riva Palacio en novelas como Monja y casada, virgen y mártir (1868) y Martín Garatuza (1868). 
dor, representado casi invariablemente por la autoridad virreinal o eclesiástica; por otro lado, el criollo idealizado, epítome de todos los valores humanos y libertarios. Las tensiones entre ambos arquetipos desarrollan la acción, la que configura y estigmatiza a la Colonia como un lugar de atraso, superstición y represión inhumana, que coarta la realización plena del hombre. De esta manera, la novela histórica antiespańolista articula un imaginario discursivo e imaginativo a partir del cual explica y justifica histórica y humanamente la independencia de México.

El segundo gran momento de la novela histórica en México durante el siglo XIX abarcará entre finales de la década de 1850 y mediados de la de 1870, coexistiendo con las resoluciones artísticas anteriores. ${ }^{5} \mathrm{Y}$ es que a finales de la década de 1850 , desde la perspectiva liberal, comienzan a plantearse nuevas resoluciones éticas y estéticas por parte de narradores como Juan Díaz Covarrubias en Gil Gómez el Insurgente (1858) o, posteriormente, Juan Antonio Mateos en Sacerdote y caudillo y Los insurgentes -ambas de 1868-, José Tomás de Cuéllar en El pecado del siglo (1869), Vicente Riva Palacio, Guillermo Prieto, Rafael Martínez de la Torre y Juan Antonio Mateos en El libro rojo (1870), ${ }^{6}$ Enrique de Olavarría y Ferrari en Episodios históricos mexicanos (1880-1883), Demetrio Mejía en Entre el amor y la patria (1889), Ireneo Paz en Leyendas históricas de la independencia (1894), por mencionar unas cuantas.

\footnotetext{
${ }^{5}$ Recuérdese que, a final de cuentas, los alcances temporales de los periodos históricos y culturales, literarios, son aproximativos, y, al ser procesos dialécticos, generan desde su seno los factores que llevarán a su destrucción, su superación y trascendencia. Por ello, muchas veces se da una coexistencia conflictiva, hasta que desaparece el que automatiza su percepción.

${ }^{6} \mathrm{Si}$ bien El libro rojo compendiaba los momentos de crisis históricas y las muertes vividas por México y los mexicanos a lo largo de su historia -de allí lo sensorial y sinecdóquico del título-, la resolución discursiva de la obra se apoya conscientemente en los elementos composicionales propios del género narrativo.
} 
La intención de estos textos ya no es expresar un amor patrio o nacionalismo criollo, sino explicar y concatenar los orígenes de la independencia del país con los postulados de la ideología y modelo liberal, justificando así la validez histórica y cultural, humana sobre todo, de su proyecto de nación. Fundamental para el desarrollo de la propuesta novelesca es el hecho de que las obras entablan un debate directo con la interpretación de la gesta emancipatoria articulada por los historiadores e intelectuales conservadores (Bobadilla, 2012), al desarrollar lo que bien podría denominarse como la novela histórica de la independencia o de la mistificación liberal. $\mathrm{Y}$ es que en esta vertiente de la novela histórica mexicana el texto novelesco funciona como un discurso contestatario, que intencionalmente busca reescribir la historia de la independencia de México. Para esto, el narrador asume una perspectiva idealizante, mitificadora, que determina tanto la configuración de los personajes -Hidalgo, Aldama, Allende- como la articulación de un discurso narrativo exaltado (un tanto retórico, hay que reconocerlo), con el que se entra en debate con otras interpretaciones históricas, por lo que el enunciado artístico se erige como un discurso que reintegra, que busca reintegrar, una verdad fidedigna.

A esta formulación narrativa le sucede y/o coexiste en algunos casos, condicionada por las coyunturas históricas de la Intervención Francesa y el Imperio de Maximiliano (1862-1867), la resolución que podría denominarse como la novela histórica de la consolidación liberal, entre 1868 y 1906, de la cual son manifestaciones textos como Calvario y Tabor (1868), de Vicente Riva Palacio; El cerro de las Campanas y El sol de mayo ambas de 1868, de Juan Antonio Mateos; Clemencia (1869), de Ignacio Manuel Altamirano; Algunas campañas (1885), de Ireneo Paz; Perucho, nieto de Periquillo (1897), de autor anónimo, y los Episodios nacionales mexicanos, de Victoriano Salado Álvarez. Es común denominador a estos textos la configuración tanto de una nueva imagen del hombre en 
México que se identifica con el mestizo, así como también una novedosa representación del espacio-tiempo de la República Restaurada como el lugar de la utopía alcanzada, que articula una interpretación de la historia como la superación y cancelación de un caótico pasado (imperial e intervencionista) a un congruente presente del liberalismo triunfante que se finca y consolida en una paz y progreso humano y material plenos. En este contexto, hay que señalar que el discurso novelesco se configura, generalmente, como una memoria que concientiza las contradicciones del pasado como mecanismo para reconocer y salvaguardar la congruencia del presente.

Con esta apretada síntesis he tratado de exponer los orígenes y el desarrollo que tuvo la novela histórica decimonona en México durante el periodo en el que fue la resolución ética y estética dominante, entre 1836 y 1870, aunque continuó manifestándose con posterioridad a esas periodizaciones que son aproximativas, no definitivas. Muchas de las características del surgimiento y desarrollo de la novela histórica dentro de la naciente tradición literaria mexicana fueron resultado de la confluencia de diversos condicionantes: la necesidad por articular un imaginario y un discurso nacionalista ante diversas coyunturas históricas, así como el auge y apoyo que la prensa y las publicaciones periódicas, posibilitaron la definición de una tradición propia, la influencia de diversos modelos y perspectivas. Sin embargo, como he intentado mostrar hasta aquí, fue determinante la concepción de lo poético y sus distintas realizaciones como parte de las Bellas letras, pues estableció tanto la función ética como la formalización composicional y estilística que la particularizó como discurso. Con esto me refiero a la comprensión y definición de lo literario no ya en su dimensión de resolución ficcional individual/original, sino como discurso capaz de articular y convocar un orden posible y real, modélicamente estable, cuya autenticidad y legitimidad estaban determinadas por 
la concepción de lo escrito como reflejo o representación de la realidad.

De esta manera, el reconocimiento de las diversas formulaciones poéticas de la historia -esto es las novelitas históricas antiespañolistas y de folletín, la novela de la independencia y la novela de la consolidación liberal-, gracias a las cuales se articularon sendas imágenes y discursos específicos sobre los periodos o momentos sobre los que se fincó la identidad y la historia de México -la Colonia (1521-1821), la primera y la segunda independencia (18101821 y 1863-1867 respectivamente)-, se revelan como parte de un proceso historiográfico literario y cultural necesario a partir del cual puede comenzar a comprenderse de una manera un poco más plena y compleja el desarrollo de nuestra tradición literaria, a la vez que pueden comenzar a replantearse los modelos historiográficos a partir de los cuales entendemos nuestro propio desarrollo ético y estético.

Ahora bien, así como se reconoce que fue el género narrativo y literario dominante en nuestra tradición durante los tres primeros cuartos del siglo XIX (al menos hasta mediados de la década de 1870), debe asumirse también que, luego de consumada la segunda independencia de México en 1867 con la caída del imperio franco-mexicano de Maximiliano de Habsburgo y la restauración de la República liberal y positivista al menos hasta 1911, la novela histórica entró en el ocaso de su cultivo y desarrollo dentro de la tradición novelesca mexicana moderna a partir de los condicionantes que impuso su contexto. Por ello, con la intención de comenzar la reflexión en torno a esta parte del proceso, apunto algunos de los elementos que condujeron al declive de la novela histórica dentro de la tradición narrativa moderna en México. 
Luego del fusilamiento de Maximiliano de Habsburgo el 19 de junio de 1867 , la entrada triunfal de Benito Juárez a la capital del país el 15 de julio del mismo año supuso simbólicamente el triunfo y la restauración definitiva del liberalismo en México. Con ello, no sólo se restablecía la legalidad democrática que la intentona monárquica conservadora y clerical había pretendido desbancar y cuya representatividad retuvo obsesivamente el político oaxaqueño, sino que, más importante quizás, se legitimaba histórica y definitivamente el modelo de nación republicana y liberal ante los ojos tanto de los mexicanos como los del mundo.

Juárez y su gabinete celebraron varias reuniones de trabajo a partir del 20 de julio de 1867 con el fin de reorganizar la vida pública del país, maltrecha y en bancarrota luego de cuarenta y seis años de luchas intestinas y de cuatro guerras con potencias extranjeras. Se partió de la certeza de que en México

hay educación que dar a la juventud, hay necesidad de vías de comunicación, de impulsar la labranza en los campos, de ocuparse de la íntegra reposición de los terrenos, de la explotación de minerales, de la seguridad de los caminos, de la colonización, de la persecución de los bárbaros, o mejor dicho de su civilización, de la vigilancia de nuestras costas para evitar el contrabando, de evitar el agio y contratos ruinosos, de establecer líneas telegráficas, etcétera, etcétera (Ortiz apud. Alvarado, 2007: 20).

Como resultado de los diversos análisis efectuados en esas reuniones que tenían la intención de comprender los obstáculos que en el pasado había enfrentado la implementación de un proyecto de nación en general, de un proyecto liberal-reformista en particular, a la vez que de definir las condiciones necesarias posibles para superar ese caos y anarquía, se planteó que el problema tenía su raíz, sí, en la inestabilidad social, política, económica, histórica en suma, que propiciaban las ambiciones y los intereses de individuos 
o de partidos, al frente de la cual estaba casi siempre algún militar; pero, sobre todo, se planteó y asumió que el origen fundamental de esa inestabilidad, de esa pobreza y atraso material, de los bandazos políticos experimentados por los mexicanos, tenía por base la insubsistente o, en algunos casos, nula educación del pueblo, que no sólo lo hacía ser apático y, por tanto, permisivo con los deseos e intereses del otro, sino que le impedía verse y entenderse como parte viva, dinámica y determinante del fluir de la colectividad. Es en este contexto que surgen con un perfil protagónico los conceptos o procesos básicos a partir de los cuales se busca alcanzar, supuestamente, el desarrollo material de la colectividad, del país, y el reconocimiento del concierto de las naciones tan deseados, los cuales referían a la consecución de la paz pública por medio de la educación y ésta como medio para alcanzar el progreso material de la sociedad. Estos conceptos se consolidarían como preceptos fundamentales en la época comprendida entre 1867-1911 aproximadamente. Como dice María de Lourdes Alvarado, con el triunfo de la causa liberal la clase gobernante pudo visualizar el porvenir a partir de una visión más objetiva de su realidad e idiosincrasia, lo cual la llevó a concluir que las notables diferencias que nos caracterizaban y separaban frente a los modelos europeo y anglosajón, así como el fracaso de los regímenes constitucionales posindependentistas, se debía en gran medida a la falta de preparación del pueblo (2007: 23).

En esta coyuntura moral y formativa, reconocida y asumida por la República Restaurada, en el marco de las festividades organizadas en la ciudad de Guanajuato para celebrar el cuadragésimo séptimo aniversario del inicio de la independencia, el médico Gabino Barreda pronunció una disertación muy en consonancia con los dilemas y contradicciones reconocidos por el gobierno juarista. Dicha alocución se titulaba "Oración cívica", la cual, al asumir como marco teórico explicativo de la circunstancia mexicana el 
modelo histórico de la filosofía de Augusto Comte, entendía la República Restaurada como el estadio histórico positivo que haría posible el progreso material de México. En ese contexto, la educación cumplía con un papel fundamental, al posibilitar una emancipación mental, intelectual, con respecto de los estadios históricos previos, enfatizando el papel regenerador humano e histórico, individual y colectivo, que cumplía la instrucción en esa coyuntura.

El gobierno juarista tuvo conocimiento del discurso de Barreda y sus planteamientos, integrando al médico a su equipo de trabajo. $\mathrm{Y}$ es que

la Oración Cívica no sólo fue una alocución más que pudiera darse a propósito de un evento histórico, sino que aquel evento histórico fue el pretexto y sustento más fuerte de un complejo de ideales que tratarían de cambiar la realidad nacional.

Al pronunciar la Oración Cívica, Barreda presenta el sustento ideológico de un proyecto de nación que impactaría en diversos ámbitos, entre ellos, el ámbito educativo nacional (Chávez, 2015).

Así, como resultado concreto de esas sesiones de análisis y discusión, el 30 de agosto de 1867 se nombró la Comisión de Instrucción Pública y Bellas Artes conformada por Eulalio Ortega, Francisco Díaz Covarrubias, Antonio Martínez del Río, Agustín Aragón y a la que, como dije, se incorporó Gabino Barreda a principios de octubre. La comisión concluyó su labor el 2 de diciembre del mismo año con la aprobación y publicación de la "Ley de instrucción pública”. En esa legislación se establecía la organización y dirección del estado en el proceso pedagógico de los mexicanos, entendiéndose la educación como un proceso formativo integral del individuo, que inicia con la escuela primaria y concluye con la educación profesional. En ese marco, la educación primaria se plantea como un nivel obligatorio, gratuito y laico, y la educación preparatoria y superior como la formadora intelectual de los 
mexicanos. De esta manera, se buscaba formar hombres y mujeres capaces de ceder en su individualidad en aras del beneficio y progreso de la República. Estos planteamientos fueron celebrados e implementados no sólo por los políticos juaristas -como los ya mencionados Martínez del Río, Ortega, Díaz Covarrubias, Aragón o Barreda- sino también, y más importante quizás, por escritores e intelectuales renombrados e influyentes como Ignacio Manuel Altamirano, Ignacio Ramírez, Rafael Zayas Enríquez, Manuel M. Flores, Francisco Sosa, entre otros.

Ante esta realidad reconocida y asumida por la República Restaurada, surge de inmediato el interrogante de cuáles fueron las diferencias entre el proyecto educativo juarista/positivista y los proyectos educativos previos del mismo siglo, de entre los que destaca por su carácter cívico/ideológico el de mexicanización de la literatura y la cultura que habían diseńado y preconizado la Academia de Letrán y sus adláteres durante el periodo comprendido entre 1830 y 1870 aproximadamente, mismos quedesempeńaron el papel fundamental de articular aquellas imágenes, valores, discursos e instituciones a partir de los cuales darle justificación y sentido a la independencia alcanzada, vía las diversas formalizaciones de las Bellas Letras (historia, derecho, filosofía, poesía). Considero que la diferencia principal radica en el hecho de que, como había sido durante la época colonial, la formación educativa de los ciudadanos fue, hasta el triunfo de la República Restaurada en 1867, una actividad ejercida ya por las órdenes religiosas ya por las asociaciones privadas de caridad (quizás, sí, con la supervisión laxa de un estado centrado en su definición y consolidación), cuya tarea era formar moralmente al pueblo en los valores establecidos desde la perspectiva o visión del mundo de esos individuos o gremios. En este sentido, pues, el proyecto de mexicanización de la cultura y la literatura, desarrollado por la asociación lateranense y sus émulas, respondía a la comprensión y las dinámicas educativas de su con- 
texto y tradición, mucho más libres y espontáneas; sin embargo, por ser más relajadas y diversas, y por tanto no necesariamente encaminadas a una misma finalidad o propósito material colectivo, es necesario reconocer que era lo que necesitaba el país en la circunstancia histórica independentista y nacionalista del momento. Por ello, la concepción y organización de la República Restaurada como aquella entidad que orquestaría todos los órdenes de la vida pública, la educación uno de los principales, en aras de alcanzar un objetivo y progreso común, fue una estructura institucional tan novedosa, moderna y propositiva en su momento. $\mathrm{Y}$ es que, en esa circunstancia, la institucionalización del ámbito educativo cumplió con el papel fundamental de ser uno de los aparatos ideológicos de un estado que -reitero: en aquel momento- se reconocía como una posibilidad real para ubicar al país dentro del concierto moderno de las naciones. Esto dio inicio a un cambio de paradigmas con el cual no sólo la educación sino la literatura comienzan a reconfigurarse y a adquirir nuevos sentidos y funciones.

Ante el prestigio y predominio cultural que adquiere la educación positiva como camino hacia la paz y el progreso material, en México comienza a gestarse el cambio de modelo y comprensión del concepto y campo cultural de las Bellas letras en general, de lo poético en particular - proceso que, por lo demás, se estaba dando también en el resto de occidente-, por lo cual aquéllas pierden su significación y vigencia y comienzan a disgregarse para conformar nuevos campos cognoscitivos y culturales, acordes a las imperantes positivistas del entorno filosófico e intelectual. Por eso, surgen y se definen las ciencias sociales, como sucede con la historia y el derecho, y las ciencias humanas, como sucede con la filosofía, la psicología, la pedagogía y la lingüística. En este contexto, el espacio y la función histórica y moral que milenariamente había cumplido la poesía como una de las formalizaciones concretas de un espectro significativo más amplio y encaminado a ilustrar moralmente al 
pueblo, comienza a entenderse como un concepto y campo específico, dedicado a la búsqueda de las más "sublimes aspiraciones" del hombre, la belleza, y se hermanaba su significado y función sólo con la estética y las Bellas artes (pintura, danza, música, escultura); es decir, con el conocimiento y manejo de una técnica para lograr un ideal estético determinado. Jorge B. Rivera explica el proceso de profesionalización de la literatura en Argentina, pero su aproximación bien podría hacerse extensiva al resto de las tradiciones culturales y literarias de Hispanoamérica:

a lo largo del siglo XIX, la literatura cumplió en nuestro país [y en nuestro continente] un papel netamente político y social pedagógico, de carácter práctico y militante. Es a partir de 1880 cuando se acentúa el carácter autónomo del discurso literario [...] Es precisamente el Modernismo el que aporta la idea -hasta entonces inusual- de una literatura puramente artística: sus intelectuales parecen relativamente divorciados de la idea del poder. "Rebasados por un medio que sienten fundamentalmente como utilitario, sensualista y antiartístico (...) los jóvenes intelectuales modernistas abjuran el papel de mentores del proyecto burgués" (1998: 63).

Una de las primeras expresiones o planteamientos en el cambio de la concepción de la literatura en México la articula Manuel Gutiérrez Nájera, quien publica los reveladores ensayos "El arte y el materialismo" (1876) y "El movimiento literario en México" (1881), los cuales manifiestan no sólo el agotamiento y cansancio ante los paradigmas nacionalistas y formativos prestablecidos por las Bellas letras, sino que apuntan algunos de los valores y actitudes que ayudarán a definir y particularizar tanto la nueva estética a la que posteriormente se llamará Modernismo, como la nueva concepción y función que adquiere la literatura:

lo que nosotros queremos, lo que siempre hemos defendido, es que no se sujete al poeta a cantar solamente ciertos y determina- 
dos asuntos, porque esa sujeción, tiránica y absurda, ahoga su genio y sofocando tal vez sus más sublimes aspiraciones, le arrebata ese principio eterno que es la vida del arte, ese principio santo que es la atmósfera del poeta, y sin el cual [...] el hombre siente que su espíritu se empequeñece, que sus fuerzas se debilitan, y muere, por último, en la abyección y en la barbarie (Gutiérrez Nájera, 2002: 9-10).

Concluye esta idea diciendo que querer que los bardos "tergiversando sus inspiraciones vengan a cantar [sólo] a la patria, al progreso, a la industria, es imponer un yugo tiránico a los poetas, es pretender un imposible, un absurdo" (2002: 11).

Ante este orden de cosas, señala que su aspiración es la belleza, pero no entendida como una copia o imitación de una idea o de la naturaleza según los presupuestos de la estética romántica ni, de manera general, según los presupuestos deterministas del realismonaturalismo, sino concebida como "la imagen de una idea" (2002: 15) que deslumbra y que sorprende y que se puede encontrar en nuevas percepciones del mundo que no se ajustan a la lógica del racionalismo materialista y positivista. En este sentido, la propuesta de Gutiérrez Nájera (que comparten y desarrollan individualmente los otros miembros de esa generación de escritores a los que suele identificarse como la primera generación modernista, como Salvador Díaz Mirón, Manuel José Othón, Manuel Puga y Acal, Carlos Díaz Dufoo y Luis G. Urbina entre otros, a los que sólo posteriormente se les dará el nombre de "modernistas") presenta ecos o significaciones emparentadas más que con el idealismo en el sentido platónico y con los planteamientos impresionistas que buscaban captar la belleza y/o lo sorprendente en el efecto o impresión fugaz del instante de la acción y no en la identificación y análisis realista-naturalista, materialista-positivista.

En esa época de cambios que, independientemente de ser positivos o negativos, definieron toda una etapa comprendida entre los 
años de 1868 y 1911 (el juarismo y el porfiriato), y que determinaron y siguen determinando en mucho la comprensión y función social de la literatura en nuestra tradición cultural y que continúan marcado de manera indeleble el imaginario y el horizonte de expectativas de México hasta la actualidad todavía -en los niveles político, social, económico, educativo y artístico-, la novela histórica mexicana del siglo XIX continuó manifestándose, sobre todo en sus resoluciones de la novela histórica de la consolidación liberal (1868-1903), cuyo representante más connotado durante ese periodo fue Victoriano Salado Álvarez, con sus Episodios nacionales mexicanos (1902-1904) - por no mencionar al autor anónimo de Perucho, nieto de Periquillo (1897)-, obra que coincidió, en un principio, con algunas realizaciones de la novela histórica antihispanista de folletín -en la que destacan, como ya señalé, las novelas maestras de Vicente Riva Palacio referidas al ciclo colonial-.

Hay algo que me llama particularmente la atención en este contesto: la idea, sobre todo, y la función de la historia manejada en esas obras. Y es que, como señalaba antes, en el nuevo contexto liberal/positivista, la concepción de la historia, de la novela histórica misma, cambia, como señala el propio Vicente Riva Palacio en las "Consideraciones generales" a México a través de los siglos, la magna obra histórica que el liberalismo triunfante emprendió entre 1884 y 1889 para justificar y legitimar su acceso al poder. En esas líneas iniciales consideraba que

la historia detallada y minuciosa de los sucesos y de las personas va separándose de la historia sin personajes, y aunque mutuamente prestándose auxilios y siéndose indispensables la una a la otra, es la segunda la que debe prestar positiva utilidad en lo porvenir, llevando por base las ciencias sociológicas y sirviéndole al mismo tiempo a esas ciencias de centro y dirección.

[...] Tiene la noticia de los pasados sucesos la importancia que darles pueda el conocimiento por ellos adquirido de la índole, del 
carácter, de las costumbres, de la naturaleza misma de los hombres y de las razas entre quienes se han efectuado; pero el minucioso trabajo de narrar o aprender detalles de aquellos acontecimientos, los nombres de los personajes y los mil incidentes ocurridos, por más que se tenga por obra de grande utilidad, sirve sólo para halagar la vanidad del escritor y la curiosidad del lector, dando copiosa fuente de inútil y laboriosa erudición (Riva apud. Sosa, 2005: 79-80; el énfasis es mío).

Considero particularmente importantes estos señalamientos por las diversas implicaciones éticas que tienen en el campo de lo literario en general, y para la formalización de la novela histórica en lo específico. Y es que, por un lado, me parece que expresan claramente el cambio de paradigma en la concepción y función de la literatura que impuso el nuevo horizonte positivista/liberal: mientras que la concepción de la historia y de la novela histórica como componentes de las Bellas Letras había implicado durante los dos primeros tercios del siglo XIX su comprensión como formalizaciones éticas y estéticas paralelas de un mismo ejercicio o campo cultural, dedicado a la sistematización de la cultura oficial a partir de la palabra escrita, en el cual ambos discursos desempeñaban un mismo papel y función. En cambio ahora, y como lo revela la cita, ambas prácticas comienzan a diferenciarse y de hecho una, la historia a secas y sin personajes, adquiere la preeminencia y responsabilidad de "prestar positiva utilidad en lo porvenir, llevando por base las ciencias sociológicas y sirviéndole al mismo tiempo a esas ciencias de centro y dirección”, afirmación reveladora acerca del papel secundario o marginal que comienza a tener la literatura a partir de ese horizonte de expectativas liberal/positivista. Por otro lado, me parece que esta reflexión de 1884 descubre una clara conciencia del autor acerca de los alcances y límites significativos tanto en la concepción como en la función cultural y social que cumplía la novela histórica dentro de los valores del mundo libe- 
$\mathrm{ral} /$ positivista que surgía. Como señalé arriba, hay una manifestación precisa de las diferencias entre dos tipos de escritura de la historia: por un lado, la historia científica y positivista (la historia sin personajes), objetiva e imparcial y, por otro lado, la historia de los personajes y los mil incidentes ocurridos, que "sirve sólo para halagar la vanidad del escritor y la curiosidad del lector, dando copiosa fuente de inútil y laboriosa erudición"; esta afirmación de Riva Palacio es paradójicamente sorprendente pues, como novelista esclarecido, mucho del reconocimiento a su capacidad intelectual y literaria la debía a su minucioso trabajo en el arte de captar y narrar los detalles de aquellos grandes acontecimientos, de ubicar y desarrollar en ellos las acciones de los personajes y los mil incidentes que podían ocurrirles.

De esta manera, desde el seno mismo del campo de la escritura artística representada por la voz de uno de sus más reconocidos exponentes, Vicente Riva Palacio, la literatura en general, la novela histórica en particular, comienza a adquirir un sentido y una significación más individualista, más lúdica y técnica, más estética en síntesis, que la hace ser comprendida y valorada -tanto intelectual como materialmente- sobre todo a partir de su capacidad formal para expresar y ser "fuente de inútil y laboriosa erudición", afirmación que desde el último tercio del siglo XIX subyace aún en la actualidad a muchas de las interpretaciones y estimaciones del arte y la literatura en nuestro entorno social y cultural.

En este tenor, llama la atención el significado y función que la historia recreada por la novela histórica adquiere entre finales del siglo XIX y los principios del XX; es decir, como curiosidad, como testimonio y memoria o extrańa o intrigante o sugestiva, tal como apunté que sucede en textos como los Episodios nacionales mexicanos, de Victoriano Salado Álvarez, quien en palabras de su narrador-testigo, el ficticio Juan Pérez de la Llana, explicita su función al asumir que "algunos que me quieren bien, y que dicen poseo 
palabra fácil y colorida, buena memoria y noticias, que ya van siendo escasas, de acontecimientos pasados, me animan a que relate las grandes cosas que presencié [en esta novelita que aquí comienzo]" (Salado, 1986: 2; el énfasis es mío).

De esta manera, y a diferencia de las distintas formalizaciones articuladas en las décadas anteriores (las novelitas antiespañolistas y de folletín y la novela de la mistificación liberal; incluso las primeras manifestaciones de la modelización de la consolidación liberal), la novela histórica escrita durante la última década de la centuria decimonona y la primera del siglo XX se da a la tarea de narrar grandes momentos de la historia nacional (el santanismo -1833-1855-, la intervención francesa y el segundo imperio (1862-1867), etcétera), tal como lo hacen Enrique de Olavarría y Ferrari y, sobre todo, el ya mencionado Victoriano Salado Álvarez. Sin embargo, el sentido de esa representación artística de la historia está en función ya no de formar o instruir a la colectividad en una determinada idea de nación, sino de recordarle un pasado y, por tanto, una experiencia colectiva que se está olvidando.

Hasta aquí he intentado mostrar que algunas de las características del surgimiento, desarrollo y ocaso de la novela histórica dentro de la tradición literaria mexicana decimonona fueron producto de la confluencia de diversos condicionantes: la necesidad de articular un imaginario y un discurso nacionalista en diversas coyunturas históricas, así como la influencia de diversos modelos y tradiciones. Sin embargo, planteo que en ese desarrollo y ocaso fueron determinantes la concepción de lo literario y sus distintas realizaciones, primero como parte de las Bellas letras y posteriormente su comprensión como una de las Bellas artes, pues ello determinó tanto la función ética como la formalización composicional y estilística que la particularizó como subgénero específico. 
De esta manera, pues, el estudio sobre el cultivo y desarrollo de la novela histórica durante el siglo XIX en México, gracias a los cuales se articularon sendas imágenes y discursos específicos sobre los periodos o momentos en los cuales se fincó la identidad y la historia de México, se revela como parte de un reconocimiento historiográfico literario y cultural necesario, a partir del cual se puede repensar y comprender de una manera un poco más plena e integral el desarrollo de nuestra tradición literaria, a la vez que pueden comenzar a reconfigurarse los modelos historiográficos a partir de los cuales explicamos nuestro desarrollo ético y estético, histórico y cultural.

\section{Bibliografía}

Almazán, Pascual, 1991, Un hereje y un musulmán, en La novela del México colonial, Aguilar, México.

Altamirano, Ignacio Manuel, 1988, "La literatura en 1870. La novela mexicana", en Obras completas. Escritos de literatura y arte, vol. XII, t. I. SEP, México.

, 1982, Clemencia, Editores Mexicanos Unidos, México.

Alvarado, María de Lourdes, 2007, et.al., Los tiempos de Juárez, UNAM, México.

Ancona, Eligio, 2015, La cruz y la espada, Conaculta, México.

Anónimo, 1984, Perucho, nieto de Periquillo, Premia Editores, Puebla, México.

,2012, Xicoténcatl, Bonilla Artigas Editores, México.

Aradra Sánchez, Rosa María, 1997, De la retórica a la teoría de la literatura: siglos XVIII y XI, Universidad de Murcia, Murcia.

Bajtin, Mijail, 1989, Teoría y estética de la novela, Taurus, Madrid. 
Barreda, Gabino, 2005, “Oración cívica”, en Ignacio Sosa Álvarez, El positivismo en México, UNAM, México.

, 2012, "Antiespañolismo, Reforma y la mitificación de la independencia en la novela mexicana del siglo XIX (18571870)", América Cahiers du CRICCAL, núm. 42, pp. 61-73.

Carballo, 1991, Emmanuel, Historia de las letras mexicanas en el siglo XIX, Xalli/Universidad de Guadalajara, México.

Carrillo Ancona, Eligio, 1984, Historia de Welina, Editorial Premia, Puebla, México.

Cuéllar, José Tomás, 2007, El pecado del siglo, UNAM, México.

Chavarin, Marco Antonio, 2017, “El pecado del siglo, de José Tomás de Cuéllar: entre la Colonia y la República Restaurada, la libertad, el orden y el progreso", Revista de El Colegio de San Luis, vol. VII, núm. 14, julio-diciembre, pp. 47-66.

Chávez, Iris Yadel, 2016, "El 16 de septiembre de 1867 en Guanajuato, Gabino Barreda pronunció la 'Oración Cívica'”. Disponible en: https://filosofiamexicana.org/2015/09/16/1867oracion-civica (Consultado: 24/VII/2016).

Díaz Covarrubias, Juan, 1989, Gil Gómez el insurgente o la hija del médico, Porrúa, México.

Riva Palacio, Vicente, Manuel Payno, et. al., El libro Rojo, Conaculta, México.

García De Arrieta, Agustín, 1797, Principios filosóficos de la literatura, t. I., Imprenta de Sancha, Madrid.

González Peña, Carlos, 1982, Historia de la literatura mexicana. Desde sus origenes hasta nuestros días, Porrúa, México.

Gunia, Inke, 2008, De la poesía a la literatura. El cambio de los conceptos en la formación del campo literario español del siglo XVIII y principios del XIX, Iberoamericana, Madrid. 
Gutiérrez Nájera, Manuel,2002, "El arte y el materialismo”, en Belem Clark de Lara y Ana Laura Zavala, La construcción del Modernismo, UNAM, México.

Jiménez Rueda, Julio, 1998, Letras mexicanas en el siglo XIX, FCE, México.

Lacunza, José María, 1985, Netzula, en Celia Miranda Cárabes, La novela corta en el primer romanticismo mexicano, UNAM, México.

Lampillas, Francisco Javier, 1789, Ensayo histórico-apologético de la literatura española, contra las opiniones preocupadas de algunos escritores modernos italianos. Imprenta de don Pedro Marín. Disponible en: https://books.google.com.mx/books/about/ Ensayo_hist\%C3\%B3rico_apolog\%C3\%A9tico_de_la_lit. html?id=_Xi4XXvrDE0C\&redir_esc=y (Consultado: 24/ VII/2016).

Lotman, Juri, 1977, Estructura del texto artístico, Itsmo, Madrid. , 1979, Semiótica de la Cultura, Cátedra, Madrid. , 1996, La semiosfera, 3 tomos, Cátedra, Madrid.

Mateos, Juan Antonio, 1986, Sacerdote y caudillo, Porrúa, México. , 1988, Los insurgentes, Porrúa, México. , 1985, El cerro de las campanas, Porrúa, México. , 1993, El sol de mayo, Porrúa, México.

Meléndez y Muñoz, Mariano, 1836, El misterioso, Imprenta de Teodosio Cruz Aedo, Guadalajara, México.

Munárriz, José Luis, 1819, Compendio de la lecciones sobre la retórica y bellas letras de Hugo Blair. Imprenta de Garriga. Disponible en: https://books.google.com.mx/books/ about/Compendio_de_la_lecciones_sobre_la_ret $\%$ C3\%B3. html?id=H_ZBAAAAYAAJ\&redir_esc=y (Consultado: 24/ VII/2016). 
Olavarría y Ferrari, Enrique, 1987, Episodios históricos mexicanos, FCE, México.

Ortiz, L. G., 2007, "Reflexiones generales" en el Diario Oficial del 11 de noviembre de 1867 apud. Ma. De Lourdes Alvarado, et.al., Los tiempos de Juárez, UNAM, México.

Oseguera de Chávez, Eva Lidia, 1991, Historia de la literatura mexicana en el siglo XIX, Editorial Alhambra, Puebla, México.

Pacheco, José Ramón, 1985, "El criollo”, en Celia Miranda Cárabes, La novela corta en el primer romanticismo mexicano, UNAM, México.

Paz, Ireneo, 1894, Leyendas históricas de la independencia. Leyenda sexta. Guerrero, Litografía y Encuadernación de Ireneo Paz, México.

Pesado, José Joaquín, 1901, “El inquisidor de México”, en Novelas cortas de varios autores, Imprenta de Victoriano Agüeros, México.

Read, John Lloyd, 1939, The Mexican Historical Novel, Instituto de las Españas, Nueva York.

Riva Palacio, Mariano, 1982, Monja y casada, virgen y mártir, Porrúa, México.

, 1982, Martín Garatuza, Porrúa, México.

, 1985, Calvario y Tabor, Porrúa, México.

Rodríguez Galván, Ignacio, 1901, "La hija del Oidor", en Novelas cortas de varios autores, Imprenta de Victoriano Agüeros, México.

, 1984, "El visitador", en Manolito el pisaverde y otros cuentos, Editorial Premia, Puebla, México,

Sierra O’reilly, Justo, 1984, La hija del judio, 2 tomos, Porrúa, México. 
Sosa Álvarez, Ignacio, 2005, El positivismo en México, UNAM, México.

Urrejola, Bernarda, 2011, "El concepto de literatura en un momento de su historia: el caso mexicano (1750-1850)", Historia mexicana, vol. 60, t. 3, núm. 239, enero-marzo.

Riva Palacio, Vicente, 2005, "Consideraciones generales" a México a través de los siglos, en El positivismo en México (Antología), Ignacio Sosa (pról., sel.), UNAM, México.

Rivera, Jorge B., 1998, El escritor y la industria cultural, Centro Editor de América Latina, Buenos Aires.

Salado Álvarez, Victoriano, 1986, Episodios nacionales mexicanos, FCE, México.

Warner, Ralph, 1953, Historia de la novela mexicana, Antigua Librería Robredo, México.

Zorrila, José, 1955, México y los mexicanos, Ediciones de Andrea, México. 